\title{
Dietary differentiation and trophic relationships in the sub-Antarctic penguin community at Marion Island
}

\author{
N. J. Adams, C. R. Brown* \\ Percy FitzPatrick Institute of African Ornithology, University of Cape Town, Rondebosch, 7700, South Africa
}

\begin{abstract}
We compared the diets of 4 co-occurring species of penguin at sub-Antarctic Marion Island in light of mechanisms thought to result in dietary differentiation. Calculation of overlap indices and correspondence analyses indicated a clear separation in the diets of the 3 penguin genera but considerable similarity between the congeneric species pair The pelagic foraging king penguin Aptenodytes patagonicus consumed mainly myctophid fish, whereas the near- to offshore foraging macaroni penguin Eudyptes chrysolophus and rockhopper penguin E. chrysocome both consumed predominantly small pelagic crustaceans, although in different proportions. The inshore foraging gentoo penguin Pygoscelis papua fed largely on benthic nototheniid fish. Although king penguins rarely take small prey, differences in diet cannot be accounted for solely on the basis of prey size selection. Different diving capabilities may have some role in dietary differentiation, however, we consider prey availability in the apparently distinct feeding zones to explain most of the differences in the diets of the 4 species of penguins at Marion Island. The daily population food requirements of the respective penguin species at the Prince Edward Islands (comprising Marion and Prince Edward islands) increased with increasing species foraging range. The mainly benthic nature of the prey in the inshore area, compared with the more easily replenished pelagic food stocks, probably explains the differences in food availability that sustain the greater food demands of the large populations of pelagic and offshore foragers.
\end{abstract}

\section{INTRODUCTION}

The Antarctic Peninsula and islands of the subAntarctic typically support large populations of up to 5 sympatrically breeding species of penguins (Wilson 1983). Separation of feeding areas and breeding schedules (Trivelpiece et al. 1987), differing diving capabilities (Trivelpiece et al, 1986) and selection for different prey size (Croxall \& Lishman 1987) may be important factors in the ecological segregation of sympatric penguin species.

Recent studies at sub-Antarctic Marion Island $\left(46^{\circ} 52^{\prime} \mathrm{S}, 37^{\circ} 51^{\prime} \mathrm{E}\right)$ and Crozet Islands $\left(46^{\circ} \mathrm{S}, 51^{\circ} \mathrm{E}\right)$ in the southern Indian Ocean have provided descriptions of the diets of the 4 different species of breeding penguins which occur at these localities, and some preliminary estimates of various foraging parameters (Adams

\footnotetext{
- Present address: Department of Zoology and Entomology, Rhodes University, PO Box 94, Grahamstown 6140, South Africa
}

1987. Adams \& Klages 1987, 1989, Adams \& Wilson 1987. Brown 1987, Brown \& Klages 1987, Ridoux et al. 1988). We compare here the diets of the king penguin Aptenodytes patagenicus, macaroni penguin Eudyptes chrysolophus, rockhopper penguin E. chrysocome and gentoo penguin Pygoscelis papua at Marion Island and evaluate factors that may be important in causing differences in diet.

The breeding schedules (Fig. 1) of the species differ markedly. In brief, king penguins take about 14 mo to raise a chick, with egg laying occurring from November to April (N.J.A. pers, obs). Gentoo penguins are resident at Marion Island throughout the year but have a more restricted breeding season, with egg laying normally starting at the end of June. However, different colonies show considerable asynchrony and failed breeders will relay (Williams 1980a). Most chicks fledge by mid-November. In contrast, breeding activities and moult of macaroni and rockhopper penguins are highly synchronized and restricted to the months October to May with a separation of some $3 \mathrm{wk}$ 

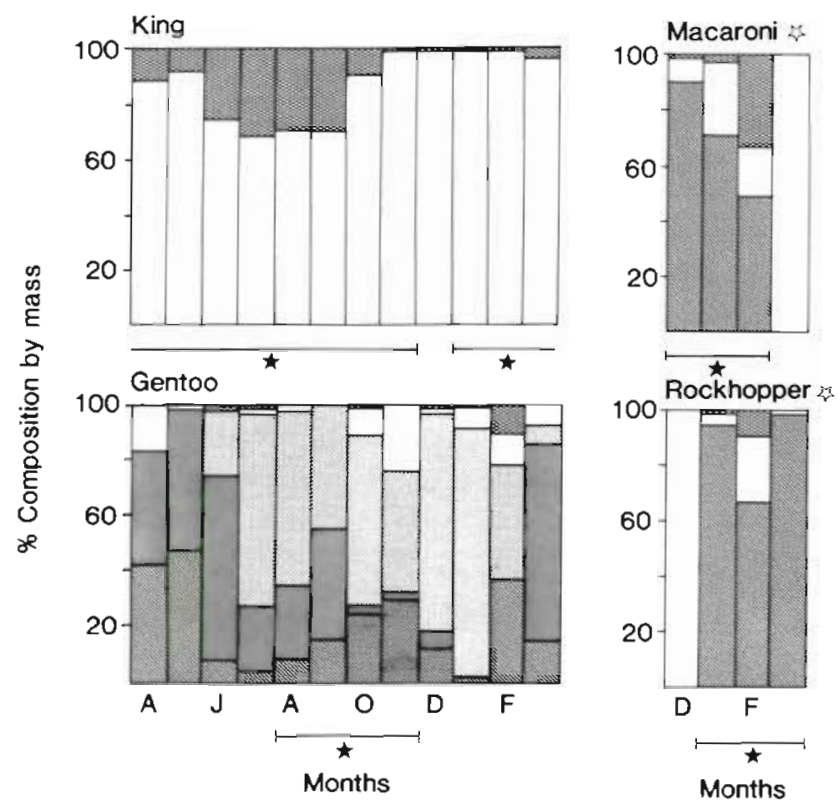

between initiation of breeding in the 2 species (Williams 1980b). Both species disperse from Marion Island during winter (Williams 1980b). During November to March all 4 penguin species are present at Marion Island and feed in surrounding waters.

\section{METHODS}

All diet samples were collected along a $9 \mathrm{~km}$ stretch of the east coast of Marion Island. Because there may be considerable interannual variation in diets of penguins at Marion Island (Brown \& Klages 1987), we concentrated here on comparisons of diet between the species based on a comprehensive set of food samples collected throughout $1 \mathrm{yr}$ only (April 1984 to March 1985). We extracted the proportions of prey identified to the lowest possible taxon by both actual and reconstituted mass and number from data of Adams \& Klages (1987, 1989), and Brown \& Klages (1987) (see Appendix 1), to perform correspondence analyses (Underhill 1981) and calculate overlap indices. Diet collection and analysis procedures are given in detail in Adams \& Klages (1987) and in Brown \& Klages (1987). Briefly, samples were obtained from adults arriving ashore after foraging or, on occasions, from large chicks immediately after being fed (king penguins only) by stomach flushing (Wilson 1984). Samples were sorted within $24 \mathrm{~h}$ of collection. Individual samples were separated into fish, cephalopod and crustacean remains and component parts weighed. Comparisons between relative mass of major prey classes are based on proportions of recovered wet mass. Fish species were identified from otoliths, cephalopods from lower beaks, and

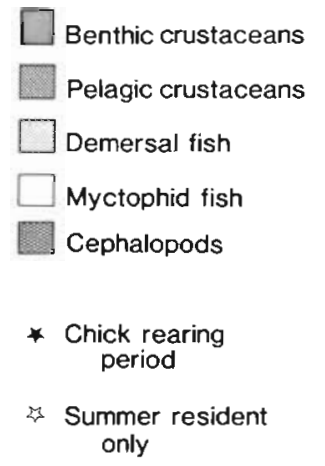

Fig. 1. Temporal variation in the proportion of the main prey classes in the diet of penguins at Marion Island (redrawn from data presented in Adams \& Klages 1987, 1989 and Brown \& Klages 1987)

crustaceans from intact individuals. Proportions by numbers and within class comparisons of well-digested prey rely on analyses of these hard parts. Unidentified prey was apportioned in the same ratio as identified prey.

Overlap in diet between penguin species was assessed using Morisita's Index (Morisita 1959) modified by Horn (1966) (see Diamond 1983). This index, which varies between 1 (complete overlap) and 0 (no overlap), is a relative measure and its value is dependent on the number of prey categories selected. We did not split categories into size classes (cf. Diamond 1983) since major taxonomic classes were generally characterized by a specific range of lengths (squid $>$ fish $>$ crustacean).

Dietary diversity between and within penguin species was compared using the Shannon index (Tramer 1969). Indices were calculated both for proportions of prey by mass for lumped samples of the 4 species (Appendix 1), and as a mean of diversity indices calculated for individual samples. We present indi-

Table 1. Diversity index of diets of penguins at Marion Island Values are given for lumped samples $\left(\mathrm{H}^{\prime}\right.$ to calculated from Appendix 1) and mean of each individual sample $\left(\mathrm{H}_{\text {ind }}\right)$ for the whole year and December to March

\begin{tabular}{|lcccc|}
\hline \multirow{2}{*}{ Species } & \multicolumn{2}{c}{ Whole year } & \multicolumn{2}{c|}{ December-March } \\
& $\mathrm{H}_{\text {tor }}$ & $\mathrm{H}_{\text {ind }}^{\prime}$ & $\mathrm{H}^{\prime}$ tor & $\mathrm{H}_{\text {ind }}^{\prime}$ \\
\hline King penguin & 0.570 & 0.296 & 0.537 & 0.337 \\
Gentoo penguin & 0.753 & 0.116 & 0.765 & 0.198 \\
Macaroni penguin & & & 0.810 & 0.345 \\
Rockhopper penguin & & & 0.518 & 0.256 \\
\hline
\end{tabular}


ces calculated for the whole year and, where appropriate, for samples recovered from December to March only (the period when all species of penguins are present at the island) (Table 1 ).

Measurements of potential foraging ranges are described in Adams (1987), Adams \& Wilson (1987) and Brown (1987) and were obtained during the same year as intensive diet sampling.

\section{RESULTS}

There were seasonal changes in the proportions (percent wet mass recovered) of major prey types of penguins at Marion Island (Fig. 1). In absolute terms, king penguins consumed the largest number of taxa (Appendix 1). However, the diversity index (Table 1) gives little weight to taxa occurring in small proportions and macaroni penguins were consequently identified by the Shannon index as having the most diverse diet, whether indices were calculated from lumped samples or from the mean of individual samples (Table 1). Lumped sample diversity was, not surprisingly, always greater than the mean of individual diversity. Little overlap is indicated between the diet of king penguins and gentoo, macaroni or rockhopper penguins when compared on the basis of numbers
(Table 2). In contrast, there is extensive overlap between gentoo and rockhopper penguins, and between macaroni and rockhopper penguins. Correspondence analysis illustrates the clear separation of king penguins from the other 3 species and identifies myctophid fish and squid as the prey species responsible (Fig. 2). Cructaceans common to gentoo, macaroni and rockhopper penguins account for the high overlap in diet between these species

Comparison of indices based on percentage mass increases the overlap between king penguins and other species, but reduces that between gentoo penguins and macaroni and rockhopper penguins (Table 3 ).

Table 2. Overlap in the diet of penguins at Marion Island. Prey categories selected are as given in A.ppendix 1 for proportion by numbers. GP, MP, RP: gentoo, macaroni and rockhopper penguins, respectively

\begin{tabular}{|lllll|}
\hline & GP & GP & MP & RP \\
\hline King penguin & 0.001 & 0.008 & 0.031 & 0.003 \\
Gentoo penguin & & & 0.780 & 0.943 \\
Macaroni penguin & & & & 0.920 \\
- Comparison based on samples collected over the whole \\
$\begin{array}{l}\text { year, remaining comparisons based on samples collected } \\
\text { from December to March only }\end{array}$ \\
\hline
\end{tabular}

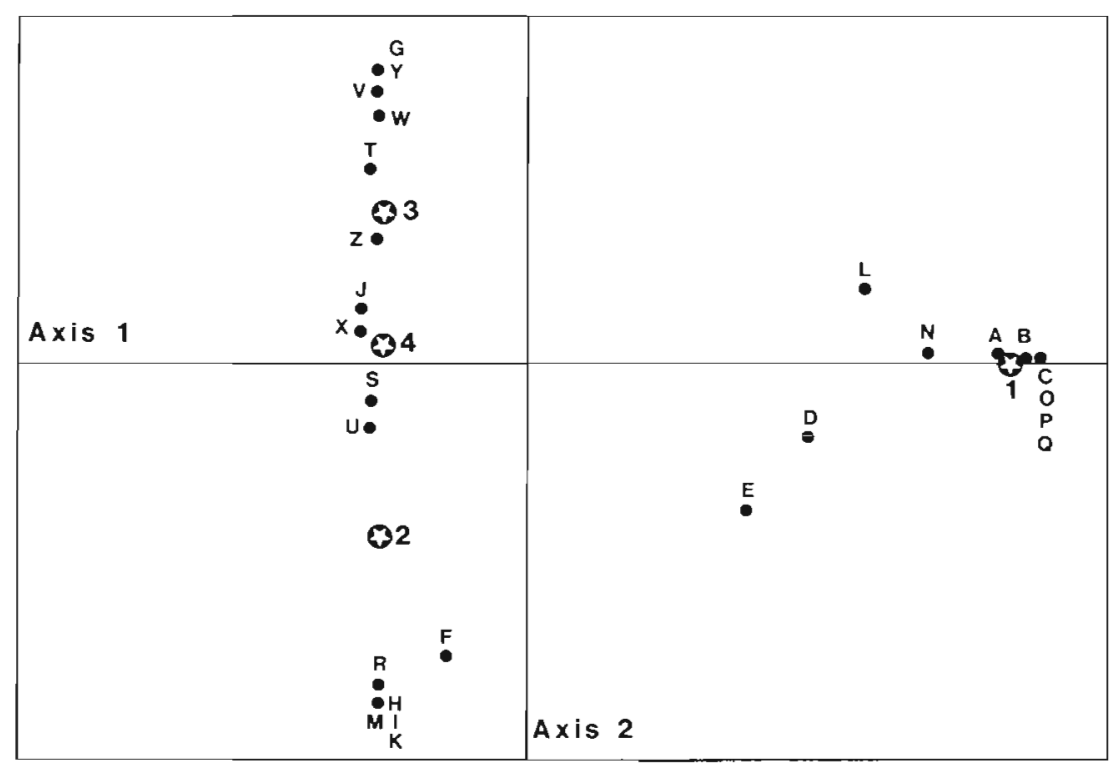

Fig. 2. Correspondence analysis of the diets of penguins at Marion Island. Penguin species with a large proportion of prey species in common plot close together. Prey consumed largely by one penguin species will plot far from the origin, whereas shared items will lie between the common predators. Data for analysis were percentage numbers from December to March only. 1: king penguin; 2: gentoo penguin; 3: macaroni penguin; 4: rockhopper penguin. A: Krefftichthys anderssoni and Protomyctophum tenisoni; B: Electrona carlsbergi; C: myctophid A; D: Protomyctophum normani; E: Protomyctophum bolini; F: Gymnoscopelus nicholsi; G: Electrona subaspera; H: Notothenia squamifrons; I: Notothenia acuta; J: Paranotothenia magellanica; K: Dissostichus eleginoides; L: Magnisudis prinosa; M: Channichthys rhinoceratus; N: Kondakovia longimana; O; oegopsid A; P: Histioteuthis sp.; Q: Brachioteuthis sp.; R: octopod A; S: Euphausia vallentini; T. Thyssanoessa vicina; U: Nauticaris marionis; V: Themisto gaudichaudi; W: Primno sp.; X: Vibilia sp.; Y. Cyllopus sp.; Z: Hyperialla sp. Mytophid A, oegopsid A and octopod A are unidentified prey species 
Table 3. Overlap in the diet of penguins at Marion Island. Prey categories selected are as given in Appendix 1 for proportion by mass

\begin{tabular}{|lcccc|}
\hline & GP & GP & MP & RP \\
\hline King penguin & $0.014^{\cdot}$ & 0.045 & 0.183 & 0.059 \\
Gentoo penguin & & & 0.293 & 0.312 \\
Macaroni penguin & & & & 0.833 \\
- Comparisons as for Table 2 & & & \\
\hline
\end{tabular}

These changes can be attributed to the increased importance of fish when diet is analysed on the basis of proportional mass. Increased separation between the diets of gentoo penguins and macaroni and rockhopper penguins is again reflected in correspondence analysis (Fig. 3), which identifies nototheniid fish as being the critical factor. Overlap between the congeneric macaroni and rockhopper penguins remains high in both comparisons.

\section{DISCUSSION}

There are inherent biases in diet analyses based on examination of stomach contents, particularly for the well-digested meals of king penguins, because soft and hard parts of different prey are digested at different rates. Crustaceans, protected by a chitin exoskeleton, are retained in seabird stomachs longer than squid flesh which in turn is retained longer than fish flesh (Wilson et al. 1985, Jackson \& Cooper 1988). Gross analyses of soft parts of prey (Fig. 1) will overestimate such prey in the order crustaceans $>$ squid $>$ fish. Relative proportions by numbers and mass of species within the major prey classes of fish and cephalopods (Appendix 1) are based on analyses of otoliths and cephalopod beaks, respectively (Appendix 1). Large cephalopod beaks may remain in the stomachs of predators for many weeks and relative proportions be overestimated (Furness et al. 1984, Jackson \& Ryan 1986). However large cephalopods, mainly in king penguin diets, form a very small proportion of the diet particularly in summer when all 4 species are on the island (Appendix 1). Most cephalopod beaks in macaroni, rockhopper and gentoo penguin diets were small (lower rostral length $<2 \mathrm{~mm}$ ) and recovered from undigested buccal masses. Residence time of otoliths in seabird stomachs ranged up to $30 \mathrm{~h}$ (Jackson \& Ryan 1986, Jackson \& Cooper 1988). Crustacean exoskeletons may remain for longer (Jackson \& Cooper 1988). Individual stomach samples aimost certainly represent prey captured during one foraging trip only. That at least $80 \%$ (by number) of individual diet samples for each penguin species was accounted for by only 4 out of a possible 35 prey taxa (Fig. 4) further reduces biases that confound interspecific comparisons. Consequently, we considered interspecific comparisons of diet composition largely justified.

Diets of Antarctic and sub-Antarctic penguins have been perceived as being dominated by a small number of prey species (but see Ainley et al. 1984). Therefore we should expect high dietary overlap, particularly between taxonomically closely related species with similar foraging methods. Although this may be true of penguins and other seabird communities at particular localities (e. g. around the Scotia Sea; Croxall et al. 1985), it is not the case at Marion Island and some other sites in the Southern Ocean region (Ainley et al. 1984). Average dietary overlap indices of the sub-Antarctic

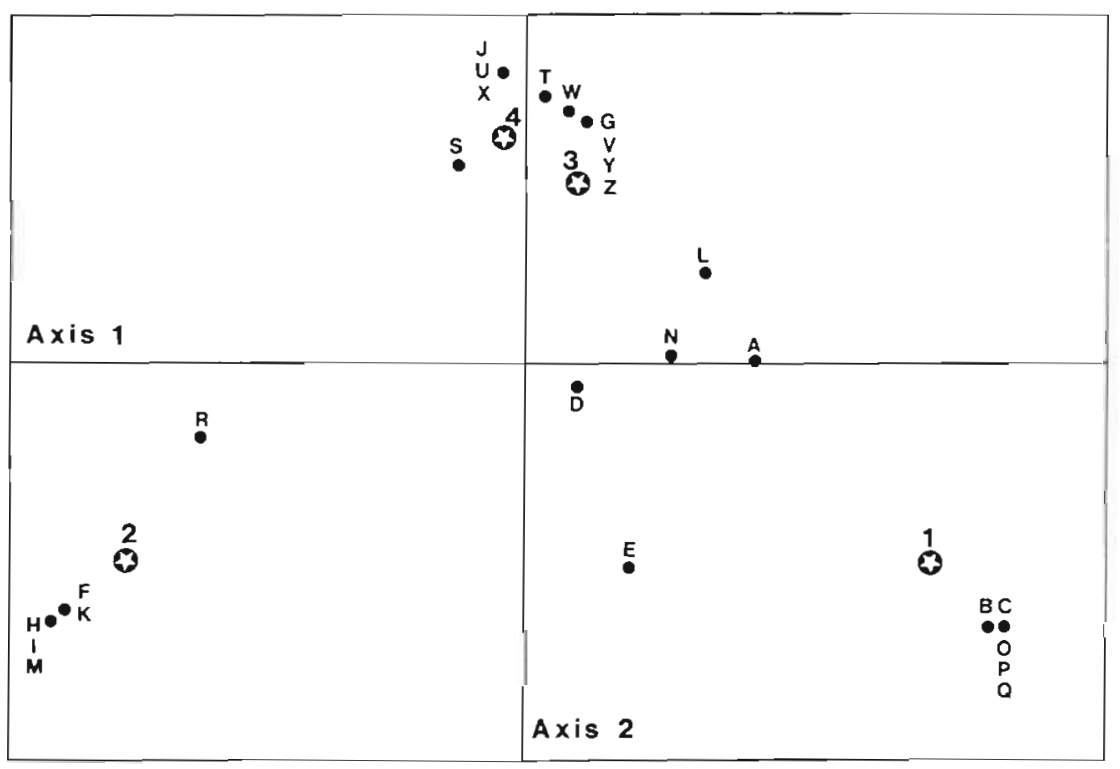

Fig. 3. Correspondence analysis of the diets of penguins at Marion Island. Data for the analysis was percentage mass for December to March only. Species codes as for Fig. 2 


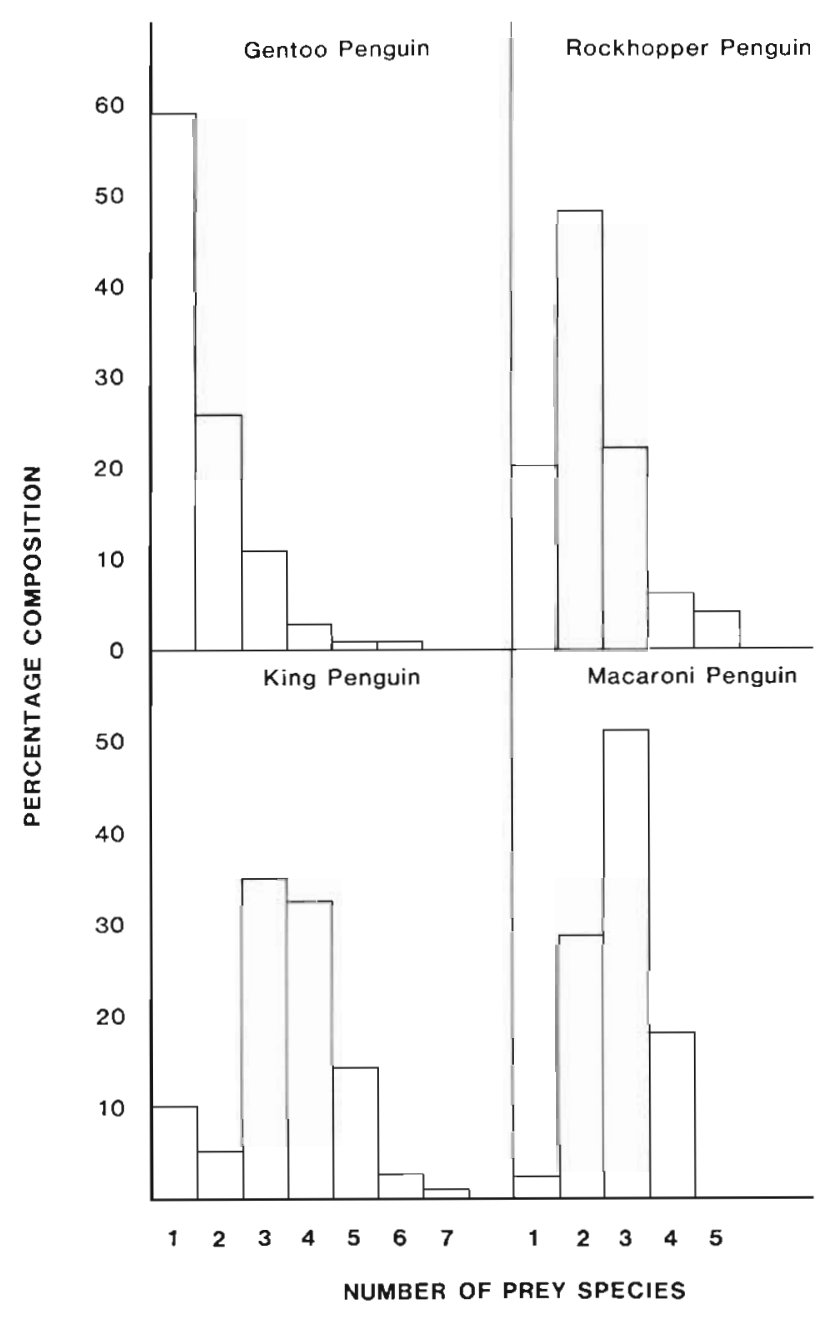

Fig. 4. Number of prey species in individual stomach samples as a percentage of total number of samples

penguin community and some Antarctic seabird communities, on a prey family basis at least, are lower than or equal to some tropical communities (Table 4).
Diversity of prey taken by foraging penguins appears to be a function both their size and foraging range. The intermediate sized macaroni and gentoo penguins are capable of taking both relatively large and small prey and have a high prey diversity compared to king and rockhopper penguins, when the diet of the sample population is considered as a whole (Table 1). The low diversity indices of gentoo penguins when diet is considered on an individual sample basis (Table 1) reflects their short nest relief periods with reduced time to encounter different prey.

\section{Differentiation mechanisms}

Prey size

Although penguins at Marion Island are capable of consuming prey ranging over 2 to 4 orders of magnitude in mass (Table 5), items are generally small (average length $<100 \mathrm{~mm}$ in all cases; Table 6) compared to those consumed by sympatric albatrosses of similar mass to penguins (Berruti \& Harcus 1978, Brooke \& Klages 1986). Minimum prey size of penguins at Marion Island was similar. However, prey of less than $30 \mathrm{~mm}$ accounted for only $6 \%$ (by number) of the diet of the large king penguin but comprised a substan-

Table 5. Maximum mass of prey items (all squid) recovered from penguin stomach samples at Marion Island. All penguins were capable of taking prey of $0.1 \mathrm{~g}$, the minimum size we estimated

\begin{tabular}{|lc|}
\hline Species & Max. mass $(g)$ \\
\hline King penguin & 807 \\
Gentoo penguin & 65 \\
Macaroni penguin & 41 \\
Rockhopper penguin & 15 \\
\hline
\end{tabular}

Table 4. Average overlap indices of diets within seabird communities. Analysis categories are prey family by percent numbers and mass as indicated

\begin{tabular}{|c|c|c|c|c|}
\hline \multicolumn{2}{|c|}{ Overlap index } & \multirow{2}{*}{$\begin{array}{l}\text { No. seabird } \\
\text { species }\end{array}$} & \multirow[t]{2}{*}{ Locality } & \multirow[t]{2}{*}{ Source } \\
\hline No. & Mass & & & \\
\hline 0.84 & 0.73 & 5 & Aldabra Atoll, tropical & Diamond 1983 \\
\hline 0.49 & 0.44 & 5 & Cousin Island, tropical & Diamond 1983 \\
\hline 0.51 & - & 11 & Christmas Island, tropical & Diamond 1983 \\
\hline 0.51 & 0.43 & $4^{a}$ & Marion Island, sub-Antarctic & This study \\
\hline 0.73 & - & 9 & Farne Island, temperate & Diamond 1983 \\
\hline 0.77 & - & 7 & Oceanic, Antarctica & Ainley et al. 1984 \\
\hline 0.60 & - & 6 & Continental slope, Antarctica & Ainley et al. 1984 \\
\hline 0.41 & - & 3 & Continental shelf, Antarctica & Ainley et al. 1984 \\
\hline a Penguins & & & & \\
\hline
\end{tabular}


Table 6. Mean length of prey species recovered from stomachs of penguins at Marion Island. Fish: standard length; cephalopods: dorsal mantle length; crustaceans: total length

\begin{tabular}{|c|c|c|c|c|}
\hline & \multicolumn{4}{|c|}{ Mean length (mm) } \\
\hline & $K P$ & $G P$ & MP & $\mathrm{RP}$ \\
\hline \multicolumn{5}{|l|}{ FISH } \\
\hline \multicolumn{5}{|l|}{ Myctophidae } \\
\hline Kreffichthys anderssoni & 48.3 & 49.6 & 37.3 & 19.4 \\
\hline Protomyctophum tenisoni & & 49.2 & 49.5 & 45.9 \\
\hline Electrona carlsbergi & 82.3 & - & 76.6 & - \\
\hline Protomyctophum normani & 79.7 & 77.7 & 68.5 & 74.8 \\
\hline \multicolumn{5}{|l|}{ Nototheniidae } \\
\hline Notothenia squamifrons & 50.7 & 71.1 & - & - \\
\hline \multicolumn{5}{|l|}{ Channichthyidae } \\
\hline Channichthys rhinoceratus & - & 170.3 & - & - \\
\hline \multicolumn{5}{|l|}{ CEPHALOPODS } \\
\hline Kondakovia longimana & 73.0 & 58.5 & 58.4 & 60.9 \\
\hline Octopoda & - & $<10$ & $<10$ & $<10$ \\
\hline \multicolumn{5}{|l|}{ CRUSTACEANS } \\
\hline \multicolumn{5}{|l|}{ Euphausiacae } \\
\hline Euphausia vallentini & - & 22.5 & 24.0 & 24.0 \\
\hline Thysannoessa vicina & - & - & 15.0 & 15.0 \\
\hline \multicolumn{5}{|l|}{ Natantia } \\
\hline Nauticaris marionis & - & 35.1 & - & - \\
\hline \multicolumn{5}{|l|}{ Amphipoda } \\
\hline Themisto gaudichaudi & - & - & 15.0 & - \\
\hline \multicolumn{5}{|l|}{ Average prey item size } \\
\hline Total & 49.8 & 25.8 & & \\
\hline December-March & 62.0 & 30.4 & 21.5 & 22.3 \\
\hline Culmen length (mm) & 133.0 & 67.0 & 56.6 & 46.0 \\
\hline
\end{tabular}

tial proportion of the prey of the 3 other smaller penguin species. Discrimination of prey based on some minimum size may be more important than maximum size in causing differentiation of diets of large and small penguins at Marion Island.

Although ANOVA demonstrated significant differences in the mean size of myctophid fish species common to more than one species of penguin (e.g. for Protomyctophum normani in the diet of king, macaroni and rockhopper penguins, $F=164.94, F_{0.05,3,983}=2.61$, $p<0.005$ ) (see also Brown \& Klages 1987) no consistent relationships between mean fish and cephalopod size and predator size were evident (Table 6). Similarly, Croxall \& Lishman (1987) have cautioned against drawing conclusions about preferential selection for specific prey size classes based on significant differences in length recovered from conspecifics at the same locality. Maximum size of squid taken was larger than other prey types consumed and increased with penguin size (Table 5) and is probably because of ease of handling of squid compared to fish (Ashmole \& Ashmole 1967).

Notwithstanding the absence of smaller prey from the diet of king penguins, differences in the proportions of major components in the diets of gentoo, macaroni and rockhopper penguins cannot be explained by selection of prey based on size. Volkman et al. (1980) also rejected the hypothesis that the admittedly similarly sized Pygoscelis penguins partition euphausids by size.

\section{Diving depths}

If different prey characteristically occur at different depths, segregation of diet by penguins of different diving capability (Stonehouse 1967), may occur. Gentoo penguins at South Georgia $\left(54^{\circ} \mathrm{S}, 38^{\circ} \mathrm{W}\right.$ ) feeding diurnally on benthic fish generally dived deeper (54 to $136 \mathrm{~m})$ than krill-feeding macaroni penguins $(<80 \mathrm{~m}$ ) (Croxall et al. 1988). Data from Marion Island is restricted to measurements of maximum diving depth alone which indicate dives from less than $20 \mathrm{~m}$ to greater than $70 \mathrm{~m}$ (Adams \& Brown 1983). The foraging range of gentoo and rockhopper penguins may overlap extensively during early chick rearing. The presence of demersal fish in the diet of gentoo penguins but absence from that of smaller rockhopper penguins probably reflect differing diving ability. Although Croxall et al. (1988) noted that half of the dives of king penguins at South Georgia were shallower than $50 \mathrm{~m}$, the presence of mesopelagic fish and squid in the diet of king penguins may reflect their ability to dive deep (Kooyman et al. 1982).

\section{Travelling speed}

Travelling speeds of all 4 species of penguins are similar (Table 7). Maximum speeds attained during prey pursuit will be higher and may show significant differences between species. However, all 4 penguin species at Marion Island are able to catch adult myctophids and juvenile squid. We consider it unlikely that any small differences in maximum swimming speeds play a significant role in dietary segregation.

\section{Foraging range}

There are clear differences in the mean maximum potential ranges of gentoo, macaroni, rockhopper and king penguins at Marion Island (Table 7). Samples sizes on which estimates of foraging range were made are small and, in addition, data are variable. However, the duration of foraging trips of the 4 species at Marion Island (Table 7) and elsewhere support this pattern of zonation (Croxall \& Prince 1980, Williams \& Siegfried 1980, Williams 1982, Horne 1985, Adams 1987). Breeding gentoo penguins are restricted largely to inshore 
Table 7. Foraging parameters of penguins at Marion Island. Percent time swimming and estimated foraging range for adults feeding small and large chicks are presented where possible

\begin{tabular}{|c|c|c|c|c|c|c|c|}
\hline \multirow[t]{2}{*}{ Species } & \multirow{2}{*}{$\begin{array}{c}\text { Travelling } \\
\text { speed } \\
\left(\mathrm{km} \mathrm{h}^{-1}\right)\end{array}$} & \multicolumn{2}{|c|}{$\begin{array}{l}\text { Foraging duration } \\
\qquad \text { (d) }\end{array}$} & \multicolumn{3}{|c|}{$\begin{array}{c}\text { Foraging range } \\
\qquad(\mathrm{km})\end{array}$} & \multirow[t]{2}{*}{ Source } \\
\hline & & Small & Large & Smail & Large & Range & \\
\hline King penguin & 8.7 & 12.8 & 4.0 & 255 & 301 & $75-902$ & Adams $(1987)$ \\
\hline Gentoo penguin & 7.9 & \multicolumn{2}{|c|}{0.6} & \multicolumn{2}{|c|}{14} & $1-103$ & Adams \& Wilson (1987) \\
\hline Macaroni penguin ${ }^{\text {' }}$ & 7.5 & $1.0-2.0$ & $2.5-3.5$ & & 178 & $59-303$ & Brown (1987), Williams (1982) \\
\hline Rockhopper penguin ${ }^{b}$ & 7.4 & $1.0-2.0$ & $2.5-3.5$ & 33 & - & $2-137$ & Brown (1987), Williams (1982) \\
\hline
\end{tabular}

waters (Table 7). During the remainder of the year adults do not have to return regularly to the island to feed chicks and foraging ranges may increase. The difference in foraging range between rockhopper and macaroni penguins reflects the difference in chick feeding schedules of adults feeding small and large chicks at the time estimates were made (Table 7 ). Foraging range of rockhopper penguins is probably greater later in chick rearing, and that of macaroni penguins closer to shore during early chick rearing (Brown 1987). King penguins are apparently pelagic throughout chick rearing

We suggest this zonation accounts for most of the major difference in the diets of the 4 penguin species. Similarly, Trivelpiece at al. (1987) regarded differences in foraging ranges of Pygoscelis species at King George Island, Antarctica $\left(62^{\circ} 10^{\prime} \mathrm{S}, 58^{\circ} 30^{\prime}\right)$ as an important factor affecting trophic interactions. Ainley et al. (1984) have demonstrated that diets of Antarctic seabird species may be different depending on whether birds were sampled from oceanic, continental slope or continental shelf waters, presumably reflecting availability of different prey in these areas. The absence of particular prey species in the diet of one species of penguin at Marion Island but occurrence in others (Fig. 1, Appendix 1) suggests foraging zones of the different penguin species may, to some extent, be mutually exclusive. Substantial numbers of macaroni and king penguins radiating away from large colonies (essentially a point source) will be at relatively high densities in inshore waters and potential local depletion of prey resources may be too great to make foraging profitable. In contrast, the dispersion of relatively small colonies of rockhopper (pers. obs.) and gentoo penguins (Adams \& Wilson 1987) along the coastline of Marion Island may reduce intraspecific competition in inshore and nearshore waters (Croxall \& Prince 1980, Adams \& Wilson 1987).

Changes in the diets of macaroni and rockhopper penguins over chick-rearing appear to reflect a change from nearer-shore foraging during early chick rearing to offshore feeding when chicks are larger. The 3 to 4 wk separation period between the breeding peaks of macaroni and rockhopper penguins at Marion Island is of equivalent length to the guard period of small chicks. Thus the separation in timing of breeding results in differentiation of foraging zone which is, in turn, reflected in the diets of the 2 species. Timing of breeding at other localities where 2 congeneric species breed, e.g. adélie Pygoscelis adeliae and chinstrap $P$. antarctica penguins at Signy Island, are also separated by about $4 \mathrm{wk}$, equivalent to the guard period of the latter species (Lishman 1985, Trivelpiece at al. 1987). The staggering of peak food requirements of congeneric species may have an indirect role in causing dietary differences due to separation of foraging zones (see Trivelpiece at al. 1987). We are in agreement with Trivelpiece at al. (1987) and regard specific differences in diet as reflecting differences in foraging ranges, life history patterns and temporal differences in food availability rather than competitive interactions between penguin species.

Foraging range, population size and daily population food requirement

Ashmole (1963) and Diamond (1978) suggested that population sizes of breeding aerial seabirds at oceanic islands are limited by the availability of food. If the amount of food is a function of feeding area for surfacefeeding seabirds (or volume for penguins) then pelagic feeders should be more numerous than inshore feeders and migrant seabirds more abundant than resident species (Diamond 1978). Migration to alternative feeding areas outside those utilized during breeding increases effective feeding area and has a more significant effect on population size than pelagic feeding (Diamond 1978). Although, as yet, no food limitation has been demonstrated for breeding seabirds at Marion 
Table 8. Estimated breeding population size (pairs) and daily food requirements of penguins at the Prince Edward Islands (Marion and Prince Edward)

\begin{tabular}{|c|c|c|c|c|c|c|}
\hline \multirow[t]{2}{*}{ Species } & \multirow{2}{*}{$\begin{array}{l}\text { Mean } \\
\text { mass } \\
(\mathrm{kg})\end{array}$} & \multirow{2}{*}{$\begin{array}{c}\text { Feeding } \\
\text { rate }^{i} \\
\left(g d^{-1}\right)\end{array}$} & \multicolumn{2}{|c|}{ Population size } & \multirow{2}{*}{$\begin{array}{c}\text { Total } \\
\text { biomass } \\
\left(\mathrm{kg} \times 10^{3}\right)\end{array}$} & \multirow{2}{*}{$\begin{array}{l}\text { Total daily food } \\
\text { requirements } \\
\left(\mathrm{kg} \times 10^{6}\right)\end{array}$} \\
\hline & & & $\begin{array}{l}\text { Marion } \\
\text { pairs }\end{array}$ & $\begin{array}{l}\text { Prince Edward } \\
\text { pairs }\end{array}$ & & \\
\hline King penguin & $13.1^{\mathrm{b}}$ & 392 & $215230^{\circ}$ & $5000^{c}$ & 5770 & 172.7 \\
\hline Gentoo penguin & $6.4^{b}$ & 237 & $888^{d}$ & $655^{\mathrm{d}}$ & 20 & 0.7 \\
\hline Macaroni penguin & $4.0^{\mathrm{e}}$ & 190 & $405084^{i}$ & $17000^{f}$ & 3968 & 160.4 \\
\hline Rockhopper penguin & $2.5^{e}$ & 139 & $157600^{\mathrm{g}}$ & $3500^{\circ}$ & 966 & 44.8 \\
\hline \multirow{2}{*}{\multicolumn{7}{|c|}{ a Predicted from: Feeding rate $\left(\mathrm{g} \mathrm{d}^{-1}\right)=0.495$ Body Mass $(\mathrm{g})^{0704}$ (Eq. 37; Nagy 1987) }} \\
\hline & & \multicolumn{5}{|c|}{${ }^{b}$ N.J. Adams unpubl. } \\
\hline \multicolumn{7}{|c|}{ cWilliams et al. (1979) } \\
\hline \multicolumn{7}{|c|}{ Adams \& Wilson (1987) } \\
\hline \multirow{2}{*}{\multicolumn{7}{|c|}{ ES.R. Henly pers comm. }} \\
\hline & & & & & & \\
\hline \multicolumn{7}{|c|}{9 FitzPatrick Institute unpubl. } \\
\hline
\end{tabular}

Island, we tested these predictions on the penguin community at the Prince Edward Islands. Marion Island and Prince Edward Island (collectively: Prince Edward Islands) are only $22 \mathrm{~km}$ apart and we considered the islands to constitute a single breeding site. Because the body mass of king penguins is some 4 times greater than rockhopper penguins we considered daily populations food requirement, which takes account of allometric considerations, to be a more appropriate standard for comparison. There was a consistent trend of increasing daily food demand with increased aver-. age foraging range of penguins at the Prince Edward Islands (Tables 7 and 8 ). The relatively small difference in daily food demand between macaroni and king penguins (Table 8 ) may reflect the shorter residence time of the former at the islands.

Particularly during winter, gentoo penguins feed on benthic or demersal prey, largely juvenile nototheniid fish and adult shrimp, in the relatively shallow shelf waters around the island itself. Diets of the other penguin species, largely euphausiids and myctophid fish, are mostly pelagic in origin. A pelagic food source, with new stocks moving continuously into areas locally depleted by predators, can presumably support larger populations of these predators than can more sedentary demersal organisms utilized by gentoo penguins. The major current passing Marion Island is the eastward flowing West Wind Drift. However, components of the Weddell Drift and Agulhas Current System may also penetrate to Marion Island. These currents provide a feasible mechanism for introducing pelagic prey into waters surrounding Marion Island (Boden \& Parker 1986). The presence of zooplankton elements, in net hauls and penguin stomachs, more typical of subtropical and Antarctic waters (Brown 1989) suggests this is indeed occurring.
Acknowledgements. Research at Marion Island was carried out under the auspices of the South African Scientific Committee for Antarctic Research. The logistical and financial support of the South African Departments of Transport and Environment Affairs are gratefully acknowledged. Richard Knight kindly performed and interpreted the correspondence analyses. Robert Prŷs-Jones provided useful comments on the manuscript.

\section{LITERATURE CITED}

Adams, N. J. (1987). Foraging range of king penguins Aptenodytes patagonicus during summer at Marion Island. J. Zool., Lond. 212: 313-334

Adams, N. J., Brown, C. R. (1983). Diving depths of the gentoo penguin, Pygoscelis papua. Condor 85: 503-504

Adams, N. J., Klages, N. T (1987). Seasonal variation in the diet of the king penguin (Aptenodytes patagonicus) at subAntarctic Marion Island. J. Zool., Lond. 212: 475-482

Adams, N. J., Klages, N. T (1989). Temporal variation in the diet of the gentoo penguin Pygoscelis papua at subAntarctic Marion Island. Col. Waterbirds 12: in press

Adams, N. J., Wilson M.-P. (1987). Foraging parameters of Gentoo Penguins Pygoscelis papua at Marion Island. Polar Biol. 7: 51-56

Ainley, D. G., O'Conner, E. F., Boekelheide, R. J. (1984). The marine ecology of birds in the Ross Sea, Antarctica. Ornith. Monogr. 32: 1-97

Ashmole, N. P. (1963). The regulation of numbers of tropical oceanic birds. Ibis 103: 158-473

Ashmole, N. P., Ashmole, M. J. (1967). Comparative feeding ecology of seabirds on a tropical island. Peabody Mus. nat. Hist. Yale Univ. Bull. 24: 1-131

Berruti, A., Harcus, T. (1978). Cephalopod prey of the sooty albatrosses Phoebetria fusca and P. palpebrata at Marion Island. S. Afr. J. antarct. Res. 8: 99-103

Boden, B. P., Parker, L. D. (1986). The plankton of the Prince Edward Islands. Polar Biol. 5: 81-93

Brooke, M. de L., Klages, N. T (1986). Squid beaks regurgitated by Greyneaded and Yellownosed Albatrosses Diomedea chrysostoma and D. chlorophynchos at the Prince Edward Islands. Ostrich 57 203-206

Brown, C. R. (1987). Traveling speed and foraging range of 
Appendix 1. Percentage composition of food samples from penguins at Marion Island. Proportions for all samples and samples collected from December to March are given for species resident all year Myctophid A and oegopsid A are unidentified prey species. Krefftichthys anderssoni and Protomyctophum tenisoni were not separated in analysis of king penguin diets

\begin{tabular}{|c|c|c|c|c|c|c|c|c|c|c|c|c|}
\hline \multirow[t]{3}{*}{ Prey species } & \multicolumn{4}{|c|}{ King penguin } & \multicolumn{4}{|c|}{ Gentoo penguin } & \multirow{2}{*}{\multicolumn{2}{|c|}{$\begin{array}{c}\text { Macaroni } \\
\text { penguin }\end{array}$}} & \multirow{2}{*}{\multicolumn{2}{|c|}{$\begin{array}{c}\text { Rockhopper } \\
\text { penguin }\end{array}$}} \\
\hline & \multicolumn{2}{|c|}{ Annual } & \multicolumn{2}{|c|}{ Summer } & \multicolumn{2}{|c|}{ Annual } & \multicolumn{2}{|c|}{ Summer } & & & & \\
\hline & $\begin{array}{l}\text { No. } \\
\%\end{array}$ & Mass & $\begin{array}{l}\text { No. } \\
\%\end{array}$ & $\begin{array}{c}\text { Mass } \\
\%\end{array}$ & $\begin{array}{c}\text { No. } \\
\%\end{array}$ & $\begin{array}{c}\text { Mass } \\
\%\end{array}$ & $\begin{array}{c}\text { No. } \\
\%\end{array}$ & $\underset{\%}{\text { Mass }}$ & $\begin{array}{l}\text { No. } \\
\%\end{array}$ & $\underset{\%}{\text { Mass }}$ & $\begin{array}{c}\text { No. } \\
\%\end{array}$ & $\begin{array}{c}\text { Mass } \\
\%\end{array}$ \\
\hline \multicolumn{13}{|l|}{ FISH } \\
\hline \multicolumn{13}{|l|}{ Myctophidae } \\
\hline Krefftichthys anderssoni & 54.80 & 27.13 & 57.01 & 21.14 & 0.01 & 0.17 & 0.24 & 0.32 & 0.69 & 3.19 & 0.07 & 0.25 \\
\hline Protomyctophum tenisoni & & & & & 0.01 & 0.19 & 0.36 & 0.44 & 1.45 & 12.67 & 0.21 & 7.48 \\
\hline Electrona carlsbergi & 22.67 & 51.47 & 33.43 & 56.77 & 0.01 & 0.13 & 0.05 & 0.24 & 0.02 & 0.08 & & \\
\hline Myctophid A & 2.50 & 3.69 & 2.02 & 2.21 & & & & & & & & \\
\hline Protomyctophum normani & 1.68 & 2.79 & 3.85 & 9.60 & 0.20 & 2.78 & 1.54 & 6.74 & 0.35 & 7.76 & 0.11 & 6.15 \\
\hline Protomyctophum bolini & 0.40 & 0.57 & 0.33 & 0.41 & 0.01 & 0.11 & 0.25 & 0.26 & 0.00 & 0.09 & & \\
\hline Gymnoscopelus nicholsi & 0.39 & 0.55 & 0.04 & 0.05 & 0.01 & 4.98 & 0.31 & 9.51 & 0.00 & 0.04 & & \\
\hline Electrona subaspera & & & & & & & & & 0.03 & 0.79 & & \\
\hline \multicolumn{13}{|l|}{ Nototheniidae } \\
\hline Notothenia squamifrons & 0.02 & 0.02 & & & 2.50 & 33.40 & 9.02 & 36.46 & 0.00 & 0.05 & & \\
\hline Notothenia acuta & & & & & 0.01 & 0.90 & 0.11 & 0.72 & & & & \\
\hline Notothenia magellanica & 0.02 & 0.18 & & & & & & & & & 0.02 & 0.12 \\
\hline Dissostichus eleginoides & & & & & 0.01 & 0.40 & 0.08 & 0.61 & 0.00 & 0.01 & & \\
\hline Magnisudis prionosa & 0.17 & 0.25 & 0.03 & 0.04 & & & & & 0.01 & 0.10 & & \\
\hline \multicolumn{13}{|l|}{ Channichthyidae } \\
\hline Channichthys rhinoceratus & & & & & 0.20 & 9.97 & 1.56 & 22.57 & & & & \\
\hline \multicolumn{13}{|l|}{ Muraenolepidae } \\
\hline Muraenolepis sp. & & & & & 0.01 & 0.37 & & & & & & \\
\hline \multicolumn{13}{|l|}{ CEPHALOPODS } \\
\hline Kondakovia longimana & 16.73 & 12.93 & 3.48 & 9.55 & 0.01 & 1.07 & 0.19 & 2.92 & 0.38 & 13.10 & 0.04 & 1.64 \\
\hline Oegopsid A & 0.09 & 0.07 & 0.04 & 0.11 & & & & & & & & \\
\hline Histioteuthis sp. & 0.08 & 0.12 & 0.03 & 0.15 & & & & & & & & \\
\hline Alluroteuthis sp. & 0.05 & 0.08 & & & & & & & & & & \\
\hline Moroteuthis sp. & 0.05 & 0.29 & & & & & & & & & & \\
\hline Martialia hyadesi & 0.02 & 0.01 & & & & & & & & & & \\
\hline Gonatus antarcticus & 0.02 & 0.01 & & & & & & & & & & \\
\hline Galiteuthis glacialis & 0.01 & 0.01 & & & & & & & & & & \\
\hline Brachioteuthis sp. & 0.01 & 0.01 & 0.01 & 0.04 & & & & & & & & \\
\hline Octopoda & & & & & 1.20 & 1.03 & 4.60 & 3.63 & 0.02 & 0.10 & 0.16 & 1.64 \\
\hline \multicolumn{13}{|l|}{ CRUSTACEANS } \\
\hline \multicolumn{13}{|l|}{ Euphausiacea } \\
\hline Euphausia vallentini & 0.01 & 0.00 & & & 82.60 & 22.20 & 80.48 & 15.57 & 50.10 & 32.22 & 74.55 & 60.60 \\
\hline $\begin{array}{l}\text { Thyssanoessa vicina } \\
\text { Natantia }\end{array}$ & & & & & & & & & 34.11 & 21.86 & 24.25 & 19.80 \\
\hline $\begin{array}{l}\text { Nauticaris marionis } \\
\text { Amphipoda }\end{array}$ & 0.03 & 0.00 & & & 12.90 & 21.80 & 0.17 & 0.00 & & & 0.39 & 0.32 \\
\hline $\begin{array}{l}\text { Amphipoda } \\
\text { Themisto gaudichaudi }\end{array}$ & 006 & 0.00 & & & 001 & 004 & 0.27 & 0.00 & & 6.15 & 0.10 & 0.08 \\
\hline $\begin{array}{l}\text { Themisto gaudichaudi } \\
\text { Primno spp. }\end{array}$ & 0.00 & 0.00 & & & 0.01 & 0.04 & 0.21 & 0.00 & 0.48 & $\begin{array}{l}0.13 \\
0.31\end{array}$ & 0.10 & 0.08 \\
\hline Vibilia spp. & & & & & 0.00 & 0.00 & 0.01 & 0.00 & & & 0.20 & 0.16 \\
\hline Cyllopus spp. & & & & & & & & & 1.55 & 0.99 & & \\
\hline Hyperialla spp. & & & & & 0.00 & 0.00 & 0.07 & 0.00 & 0.19 & 0.12 & & \\
\hline
\end{tabular}

Macaroni and Rockhopper Penguins at Marion Island. J. Field Orn. 58: 118-125

Brown, C. R. (1989). Energy requirements and food consumption of Eudyptes penguins at the Prince Edward Islands. Antarct. Sci. 1: 15-21

Brown, C. R., Klages, N. T. (1987). Seasonal and annual variation in diets of Macaroni and southern Rockhopper penguins at Sub-Antarctic Marion Island. J. Zool., Lond. 212: 7-28

Croxall, J. P., Davis, R. W., O Connell, M. J. (1988). Diving patterns in relation to diet of Gentoo and Macaroni penguins at South Georgia. Condor 90: 157-167

Croxall, J. P., Lishman, G. S. (1987). The food and feeding ecology of penguins. In: Seabirds: feeding ecology and role in marine ecosystems. Croxall, J. P. (ed.) Cambridge University Press, Cambridge, p. 101-133

Croxall, J. P., Prince, P. A. (1980). Food, feeding ecology and ecological segregation of seabirds at South Georgia. Biol. J. Linn. Soc. 14: 103-131 
Croxall, J. P., Prince, P. A., Ricketts, C. (1985). Relationships between prey life-cycles and the extent, nature and timing of seal and seabird predation in the Scotia Sea. In: Antarctic nutrient cycles and food webs, Siegfried, W. R., Condy, P. R., Laws, R. M. (eds.) Springer-Verlag, Berlin, p. 516-533

Diamond, A. W. (1978). Population size and feeding strategies in tropical seabirds. Am. Nat. 112: 215-223

Diamond, A. W (1983). Feeding overlap in some tropical and temperate seabird communities. Stud. avian Biol. 8: 26-46

Furness, B. L., Laugksch, R. C., Duffy, D. C. (1984). Cephalopods and studies of seabird diets. Auk 101,619-620

Home, R. S. C. (1985). Diet of royal and rockhopper penguins at MacQuarie Island. Emu 85: 150-156

Horn, H. S. (1966). Measurement of 'overlap' in comparative ecological studies. Am. Nat. 100: 419-4.24

Jackson, S., Cooper, J. (1988). Use of fibre-optic endoscopes in studies of gastric digestion in carnivorous vertebrates. Comp. Biochem. Physiol. 91A: 305-308

Jackson, S., Ryan, P. G. (1986). Differential digestion rates of prey by white-chinned petrels. Auk 103: 617-619

Kooyman, G. L., Davis, R. W., Croxall, J. P., Costa, D. P. (1982). Diving depths and energy requirements of King Penguins. Science 217: 726-727

Lishman, G. S. (1985). The comparative breeding biology of Adélie and Chinstrap Penguins Pygoscelis adeliae and $P$ antarctica at Signy Island, South Orkney Islands. Ibis 127 : 84-99

Morisita, M. (1959). Measuring of interspecific association and similarity between communities. Mem. Fac. Sci. Kyushu Univ., Ser. E, Biol. 3: 65-80

Nagy, K. A. (1987). Field metabolic rate and food requirement scaling in mammals and birds. Ecol. Monogr. 57 111-128

Ridoux, V., Jouventin, P., Stahl, J. C., Weimerskirch, H. (1988). Ecologie alimentaire comparée des manchots nicheurs aux Iles Crozet. Revue d'Ecologie (Terre et la Vie) 43: 345-357

Stonehouse, B. (1967). Feeding behaviour and diving rhythms of some New Zealand shags, Phalacrocoracidae. Ibis 109: $600-605$

Tramer, E. J. (1969). Bird species diversity: components of Shannon's formula. Ecology 50: 927-929

This article was submitted to the editor
Trivelpiece, W. Z., Bengston, J. L., Trivelplece, S. G., Volkman, N. J. (1986). Foraging behavior of gentoo and chinstrap penguins as determined by new radiotelemetry techniques. Auk 103: 777-781

Trivelpiece, W Z., Trivelpiece, S. G., Volkman, N. J. (1987). Ecological segregation of adelie, gentoo and chinstrap penguins at King George Island, Antarctica. Ecology 68: 351-361

Underhill, L. G. (1981). An ASCII FORTRAN program with dynamic core allocation for correspondence analysis. Technical Report, Department of Mathematical Statistics, University of Cape Town

Volkman, N. J., Presler, P., Trivelpiece, W. (1980). Diets of pygoscelid penguins at King George Island, Antarctica. Condor 82: $373-378$

Watkins, B. P. (1987). Population sizes of King, Rockhopper and Macaroni Penguins and Wandering Albatrosses at the Prince Edward islands and Gough Island, 1951-1985. S. Afr. J. antarct. Res. 17. 155-162

Williams, A. J. (1980a). Aspects of the breeding biology of the Gentoo Penguin Pygoscelis papua. Gerfaut 70: 283-295

Williams, A. J. (1980b). The breeding biology of Eudyptes penguins with particular reference to egg size dimorphism. Ph. D. thesis, University of Cape Town

Williams, A. J. (1982). Chick feeding rates of macaroni and rockhopper penguins at Marion Island. Ostrich 53: $129-134$

Williams, A. J., Siegfried, W. R. (1980). Foraging ranges of krill-eating penguins. Polar Rec. 20: 159-162

Williams, A. J., Siegfried, W. R. Burger, A. E., Berruti, A. (1979). The Prince Edward Islands: a sanctuary for seabirds in the Southern Ocean. Biol. Conserv. 15: 59-71

Wilson, G. J. (1983). Distribution and abundance of Antarctic and sub-Antarctic penguins: a synthesis of current knowledge. Biomass Sci. Ser. 4: 1-46

Wilson, R. P. (1984). An improved stomach pump for penguins and other seabirds. J. Field Ornith. 55: 109-112

Wilson, R. P., La Cock, G. D., Wilson, M-P., Mollagee, F. (1985). Differential digestion of fish and squid in Jackass Penguins Spheniscus demersus. Ornis Scand. 16: 77-79

Manuscript first received: January 10, 1989

Revised version accepted: July 17, 1989 